\title{
がん化学療法における吃逆に対する杮滞煎液の有効性
}

\author{
大野凛太郎*，平山大樹，斎藤和悦，稲見正幸 \\ 栃木県済生会宇都宮病院薬剤部
}

\section{Clinical Efficacy of Shitei Decoction for the Treatment of Hiccups in Patients Undergoing Cancer Chemotherapy}

\author{
Rintaro Ohno*, Daiki Hirayama, Kazuyoshi Saito and Masayuki Inami \\ Department of Pharmacy, Saiseikai Utsunomiya Hospital \\ $\left[\begin{array}{l}\text { Received December 1, } 2019 \\ \text { Accepted March 12, } 2020\end{array}\right]$
}

The clinical efficacy of shitei decoction for the treatment of hiccups in patients undergoing cancer chemotherapy was retrospectively investigated. The control group was treated with metoclopramide. The clinical efficacy was assessed based on complete remission (hiccups disappeared within 2 days of administration of shitei decoction or metoclopramide), remission (hiccups disappeared $>3$ days after the administration of shitei decoction or metoclopramide), and no effect (hiccups did not disappear after the administration of shitei decoction or metoclopramide and required other drugs to be added to the shitei decoction or metoclopramide). Among the 85 patients treated with shitei decoction, 43 had complete remission, 35 had remission, and 7 had no effect. Conversely, among the 19 patients treated with metoclopramide, 5 had complete remission, 8 had remission, and 6 had no effect. Compared with metoclopramide, shitei decoction was found to be significantly more effective. Thus, these data suggest that shitei decoction is effective for the treatment of hiccups in patients undergoing cancer chemotherapy.

Key words — cancer chemotherapy, hiccups, shitei decoction, metoclopramide

\section{緒言}

吃逆は横隔膜が不随意的攣縮を繰り返した後に 急激に声門が閉塞し，空気の流入が阻止されて特 徴的な音が発生する現象である。一般的には 48 時 間以内に消失する吃逆発作が多いが，まれに 48 時間を超えて持続する持続性吃逆や 1 力月を超え て持続する難治性吃逆に発展することもある. ${ }^{1)}$

進行がんでは 1 9\%の患者で吃逆が発現してい ると報告されており, がん化学療法施行時にも吃 逆が散見される。 ${ }^{2}$ 吃逆は生命に関与する副作用で はないため, 軽視されがちであるが, 睡眠や食事 摂取の妨げとなり，患者の quality of life（QOL） や activities of daily living（ADL）を低下させる.
しかしながら, 保険診療で承認されているクロル プロマジンや，その他保険診療で承認外の薬剤を 用いても吃逆治療に難渋することがある。このよ うな背景のなかで, 当院では吃逆の治療薬として 柿帶煎液が最も使用されており，次にメトクロプ ラミド錠が使用されている。

柿帶の薬理作用は柿帶湯を用いたマウスでの基 礎研究において，抗けいれん作用が明らかにされ ている. ${ }^{3,4)}$ 臨床研究では吃逆に対する柿帶湯およ

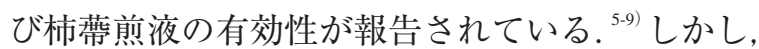
いずれもケースシリーズ研究もしくは症例報告で あり, がん化学療法における吃逆に限定し, 柿帶 煎液の有効性を検討した報告ではない。 また，化 学療法関連吃逆に対する柿帶煎液の有効性は報告

\footnotetext{
*テ321-0974＼cjkstart栃木県宇都宮市竹林町911-1
} 
されているが, 対照群を設けた検討は行われてい ない. ${ }^{10)}$ 一方で, メトクロプラミド錠は, ランダ 厶化比較試験において難治性吃逆に対して有効性 が示されている. ${ }^{11}$

そこで本研究では, がん化学療法における吃逆 に対する柿帶煎液の有効性を明らかにするため に,メトクロプラミド錠を対照群として調査およ び比較検討を行った。 なお，吃逆に対して保険診 療で承認されているクロルプロマジンは当院での 使用頻度が少なく, 対照群として設定することが できなかった.

\section{方法}

\section{1. 調査期間および対象患者}

2011 年 1 月 1 日 2016 年 2 月 29 日に当院にてが ん化学療法後に吃逆を認め, 柿帶煎液もしくはメト クロプラミド錠が開始された入院患者を対象とし た. 調查は電子カルテを用いて後方視的に行った.

また, ほかの吃逆治療薬と柿帶煎液もしくはメ トクロプラミド錠が同日中に開始された患者は対 象から除外した。なお，ほかの吃逆治療薬は吃逆 に対して有効性が報告されているガバペンチン， クロルプロマジン, クロナゼパム, バクロフェン, 䓎薬甘草湯とした。 ${ }^{12-18)}$

\section{2. 調查項目および吃逆の重症度評価}

調查項目は, 年齢, 性別, 体重, body mass index (BMI), 吃逆の重症度, がん種, 脳転移の有無, 適用レジメン, 化学療法の施行回数, cisplatin （CDDP）含有レジメンの CDDP 投与量, 柿帶煎液 およびメトクロプラミド錠以外の吃逆治療薬の使用 有無, 化学療法開始から吃逆発現までの日数（吃 逆発現日)，柿帶煎液もしくはメトクロプラミド錠 の開始日，柿掃煎液もしくはメトクロプラミド錠の 開始から吃逆消失までの日数 (吃逆消失日) とした。

吃逆の重症度評価は, 有害事象共通語基準 (National Cancer Institute Common Terminology Criteria for Adverse Events: CTCAE）ver4.0 に従っ て行った. 本研究では全患者で薬物療法が必要で あると判断されていることから Grade 2 以上で評価 した：そのなかでも睡眠に支障をきたすなどの高度
の症状を認める患者については Grade 3 と評価した.

\section{3. 柿蔕煎液調製方法および用法用量}

当院では日本病院薬剤師会監修の「病院薬局製 剂 第 6 版」に基づいて柿帶煎液を以下の手順で 調製している. ${ }^{19}$

柿帶（ウチダのシテイ $\mathrm{M}^{\circledR}$ ) $10 \mathrm{~g}$ に蒸留水 400 $\mathrm{mL}$ を加える。半量程度まで煎出し， 万過する。 煎液を蒸留水で全量 $200 \mathrm{~mL}$ までメスアップする。 これを 1 日量とし，3 回に分割して服用する.

メトクロプラミド錠は, 吃逆に対して 1 回 5 $\mathrm{mg}$ ， 1 日 3 回を服用する。

\section{4. 評価方法}

有効性は先行研究を参考に, 著効, 有効, 無効の 3 段階で評価し，それぞれ以下のように定義した. ${ }^{5,6}$ 著効：柿蒂煎液またはメトクロプラミド錠の投与 により2 日以内に吃逆が消失した.

有効：3 日以上の柿蒂煎液またはメトクロプラミ ド錠の投与により吃逆が消失した。

無効：吃逆が消失せず柿蒂煎液またはメトクロプ ラミド錠の投与が中止またはほかの吃逆治 療薬が追加投与された。

\section{5. 統計解析}

柿帶煎液投与群およびメトクロプラミド錠投与 群の背景因子比較には Student $t$-test, Mann-Whitney $U$ Test, Chi-squared test, Fisher's exact test のいずれ かを用いた，有効性の比較には Mann-Whitney $U$ Testを用いた。

なお，統計ソフトは EZR ver.1.37を用いて行っ た ${ }^{20)}$ 検定は両側検定を用い, 統計学的有意差は $P<0.05$ を有意水準とした，EZR は R および $\mathrm{R}$ コマンダーの機能を拡張した統計ソフトであり, 自治医科大学附属さいたま医療センター血液科の ホームページで無償配布されている.

\section{6. 倫理的配慮}

本研究は「人を対象とする医学系研究に関する 倫理指針」を遵守して実施し, 栃木県済生会宇都 宮病院倫理審査委員会の承認（承認番号 2015-46） を得て実施した。得られた患者情報は, 個人が特 
定できないように匿名化を施し，患者のプライバ シー保護に配慮した。

\section{結果}

\section{1. 対象患者}

柿帶煎液投与群 ( $\mathrm{S}$ 群)の対象患者は 85 例であっ た.がん化学療法による吃逆を柿帶煎液で治療し た患者 92 例のうち，ほかの吃逆治療薬と柿帶煎 液が同日中に開始された7例を対象から除外した.

メトクロプラミド錠投与群（M群）の対象患 者は 22 例であった。がん化学療法による吃逆を メトクロプラミド錠で治療した患者 24 例のうち, ほかの吃逆治療薬とメトクロプラミド錠が同日中 に開始された 2 例を対象から除外した。

\section{2. 患者背景}

患者背景を検討したところ， $\mathrm{S}$ 群および $\mathrm{M}$ 群 で性別に有意な差を認めた $(P=0.0078)$ 。また,
がん化学療法に誘発される吃逆は男性で多く発現 することが示されている. ${ }^{21-27)}$ そこで, 本研究で は男性に絞って検討することで, 性差による交絡 を制御することとした。よって，22 例のうち女 性患者3名を除外し, 解析対象患者は19例とした.

表 1 に男性患者に限定した患者背景を示す。全 背景因子において両群間で有意な差は認められな かった.

\section{3. 有効性}

表 2 に 群および M 群の吃逆に対する有効性 を示すがん化学療法による吃逆に対して, $S$ 群

表 2 有効性

\begin{tabular}{cccc}
\hline \hline & $\mathrm{S}$ 群 $(\mathrm{n}=85)$ & $\mathrm{M}$ 群 $(\mathrm{n}=19)$ & $P$ 值 \\
\hline 著効 & 43 & 5 & \\
有効 & 35 & 8 & $0.012^{\mathrm{a})}$ \\
無効 & 7 & 6 & \\
\hline
\end{tabular}

a) Mann-Whitney $U$ Test. S 群：柿帶煎液投与群， M 群：メトク ロプラミド錠投与群.

表 1 患者背景

\begin{tabular}{|c|c|c|c|c|}
\hline & & $\mathrm{S} \mathrm{S}$ 群 $(\mathrm{n}=85)$ & (M 群 $(\mathrm{n}=19)$ & $P$ 值 \\
\hline 年齢（歳） & 平均 \pm 標準偏差 & $64 \pm 11$ & $66 \pm 10$ & $0.50^{\mathrm{a})}$ \\
\hline 性別 & 男性 / 女性 & $85 / 0$ & $19 / 0$ & - \\
\hline 体重 & 平均 \pm 標準偏差 & $61 \pm 11$ & $59 \pm 8$ & $0.54^{\mathrm{a})}$ \\
\hline BMI & 平均 \pm 標準偏差 & $22 \pm 3$ & $22 \pm 2$ & $0.76^{\mathrm{a})}$ \\
\hline 吃逆の重症度（Grade） & Grade 2 / Grade 3 & $67 / 18$ & $17 / 2$ & $0.36^{\mathrm{b})}$ \\
\hline 吃逆発現日 & 中央值（範囲） & $2(1-11)$ & $2(1-6)$ & $0.36^{\mathrm{c})}$ \\
\hline 吃逆消失日 & 中央值（範囲） & $2(1-13)$ & $4(1-12)$ & $0.090^{\mathrm{c})}$ \\
\hline \multirow{10}{*}{ がん種 } & 肺がん & 37 & 15 & \multirow{10}{*}{$0.21^{\mathrm{b})}$} \\
\hline & 膀胱がん & 15 & & \\
\hline & 悪性リンパ腫 & 13 & 1 & \\
\hline & 頭頸部がん & 10 & 1 & \\
\hline & 精巣がん & 4 & 1 & \\
\hline & 食道がん & 2 & 1 & \\
\hline & 胃がん & 1 & & \\
\hline & 胸腺がん & 1 & & \\
\hline & 急性リンパ性白血病 & 1 & & \\
\hline & 多発性骨髄腫 & 1 & & \\
\hline 脳転移 & あり/なし & $18 / 67$ & $3 / 16$ & $0.76^{\mathrm{b})}$ \\
\hline 化学療法 & 初回 / 2 回目以降 & $43 / 42$ & $9 / 10$ & $1.0^{\mathrm{d})}$ \\
\hline \multirow{4}{*}{ 適用レジメン } & CDDP 含有レジメン & 45 & 12 & \multirow{3}{*}{$0.30^{\mathrm{b})}$} \\
\hline & CBDCA 含有レジメン & 23 & 2 & \\
\hline & その他 & 17 & 5 & \\
\hline & & $\mathrm{S}$ 群 $(\mathrm{n}=45)$ & $\mathrm{M}$ 群 $(\mathrm{n}=12)$ & \\
\hline \multirow{2}{*}{ CDDP 投与量 } & $70 \mathrm{mg} / \mathrm{m}^{2}$ 未満 & 11 & 5 & \multirow{2}{*}{$\left.0.29^{b}\right)$} \\
\hline & $70 \mathrm{mg} / \mathrm{m}^{2}$ 以上 & 34 & 7 & \\
\hline
\end{tabular}

a) Student $t$-test, b) Fisher's exact test, c) Mann-Whitney $U$ Test, d) Chi-squared test. S 群：柿茬煎液投与群, M 群：メトクロプラミド 錠投与群. BMI: body mass index, CDDP: cisplatin, CBDCA: carboplatin. 
表 3 BMI による S 群の有効性の違い

\begin{tabular}{cccc}
\hline \hline \multicolumn{3}{c}{ BMI } & \\
\hline & 22 以上 & 22 未満 & $P$ 值 \\
& $(\mathrm{n}=46)$ & $(\mathrm{n}=39)$ & \\
\hline 著効 & 20 & 23 & $0.20^{\mathrm{a})}$ \\
有効 & 22 & 13 & \\
無効 & 4 & 3 & \\
\hline
\end{tabular}

a) Mann-Whitney $U$ Test. BMI: body mass index.

表 4 脳転移の有無による $\mathrm{S}$ 群の有効性の違い

\begin{tabular}{cccc}
\hline \hline \multicolumn{4}{c}{ 脳転移 } \\
\hline & $\begin{array}{c}\text { あり } \\
(\mathrm{n}=18)\end{array}$ & $\begin{array}{c}\text { なし } \\
(\mathrm{n}=67)\end{array}$ & $P$ 值 \\
\hline 著効 & 11 & 32 & \\
有効 & 4 & 31 & $0.62^{\text {a })}$ \\
無効 & 3 & 4 & \\
\hline
\end{tabular}

a) Mann-Whitney $U$ Test.

表 5 化学療法の施行回数による $\mathrm{S}$ 群の有効性の違い

\begin{tabular}{lccc}
\hline \hline \multicolumn{4}{c}{ 化学療法 } \\
\hline & $\begin{array}{c}\text { 初回 } \\
(\mathrm{n}=43)\end{array}$ & $\begin{array}{c}\text { 2 回目以降 } \\
(\mathrm{n}=42)\end{array}$ & $P$ 值 \\
\hline 著効 & 20 & 23 & \\
有効 & 18 & 17 & $0.33^{\mathrm{a})}$ \\
無効 & 5 & 2 & \\
\hline a) Mann-Whitney $U$ Test. & &
\end{tabular}

表 $6 \mathrm{CDDP}$ 投与量による $\mathrm{S}$ 群の有効性の違い

\begin{tabular}{cccc}
\hline \hline & \multicolumn{3}{c}{ CDDP 投与量 } \\
\hline & $\begin{array}{c}70 \mathrm{mg} / \mathrm{m}^{2} \text { 以上 } \\
(\mathrm{n}=34)\end{array}$ & $\begin{array}{c}70 \mathrm{mg} / \mathrm{m}^{2} \text { 未満 } \\
(\mathrm{n}=11)\end{array}$ & $P$ 值 \\
\hline 著効 & 17 & 4 & \\
有効 & 16 & 5 & $0.72^{\mathrm{a})}$ \\
無効 & 1 & 2 & \\
\hline
\end{tabular}

a) Mann-Whitney $U$ Test. CDDP: cisplatin.

では M 群に比べて高い有効性を示した． $\mathrm{S}$ 群に おいて吃逆が消失した患者（著効および有効）は 85 例中 78 例 $(92 \%)$ であり，M群においては 19 例中 16 例（84\%）であった。

\section{4. 患者背景による柿帶煎液の有効性の違い}

BMI ( 22 以上, 22 未満), 脳転移の有無, 化学 療法の施行回数（初回, 2 回目以降), CDDP 投 与量 $\left(70 \mathrm{mg} / \mathrm{m}^{2}\right.$ 以上, $70 \mathrm{mg} / \mathrm{m}^{2}$ 未満) について 柿帶煎液の有効性の違いを検討した，それらの結 果を表 3〜6に示す．いずれの項目についても有 意な差は認められなかった。

\section{考察}

\section{1. 患者背景}

がん化学療法に誘発される吃逆は男性で多く発 現することが示されている. ${ }^{21-27)}$ 本研究でも交絡 を制御するために除外した M 群の女性 3 例以外 は全て男性であった。これは男性の場合, 加齢に 伴う神経機能や呼吸機能の低下により吃逆が発症 しやすくなる可能性が考えられている. ${ }^{26)}$

また, S 群の CDDP および carboplatin（CBDCA） の含有レジメンは， 85 例中 68 例（80\%）であった. 一方，M群の CDDP および CBDCA の含有レジメン は 19 例中 14 例（74\%）であった. 両群とも白金製 剂の含有レジメンで高頻度に吃逆が生じていたが, これは過去の報告と矛盾しない結果であった. ${ }^{27-29}$

\section{2. 有効性}

有効性については M 群に比べて $\mathrm{S}$ 群において, より高い有効性を示した（表 2). 従って，がん 化学療法における吃逆に対して柿帶煎液が有効で あることが示唆された。

過去の報告では, 患者背景の違いはあるものの, 柿帶湯の有効率は 52.7 66.7\%であり, 柿帶煎液 の有効率は $71.8 \sim 82.4 \%$ と報告されている. ${ }^{5-7,10)}$ 本研究の評価方法は先行研究を参考に行っている ため, ここでの有効率は本研究における吃逆が消 失した患者（著効および有効）の割合と言い換え ることができる. 5,6 この有効率は本研究では $92 \%$ （85 例中 78 例）であった。柿帶湯では柿帶が 1 日 あたり $5 \mathrm{~g}$ 含まれているのに対して, 柿帶煎液では 柿帶が 1 日あたり $10 \mathrm{~g}$ 含まれている。この柿帶の 用量の相違が有効率の相違に繋がっていると考え られる. また, 先行研究では化学療法関連吃逆に おいて柿帶煎液の効果を生じやすいことが報告さ れており, 本研究では化学療法関連吃逆に絞って 検討を行っているため, このような患者背景の相 違が有効率の相違の一因になったと考えられる. ${ }^{10)}$

本研究では $\mathrm{S}$ 群のうち, 7 例が無効例であった. このうち， 1 例は柿率煎液服用後の嘔気による中止 例であった，残りの 6 例のうち 3 例は悪性リンパ 腫の患者であったが，悪性リンパ腫とその他のが ん種に扔いて吃逆消失日や有効性の評価について 
有意な差を認めなかった。 また, 吃逆の重症度に ついても 7 例のうち 4 例が Grade 3 であり，3例が Grade 2 であり, 重症度にも偏りは認められなかっ た. よって, 本研究では柿帶煎液がどのような患者 で無効となるのかについては明確にならなかった。 今後さらに症例を集積し, 検討を行う必要がある.

\section{3. 患者背景による杮帯煎液の有効性の違い}

化学療法関連吃逆では高 BMI が柿楽煎液の薬 効を増強する身体的因子であると報告されてい る. ${ }^{10)}$ 本研究では BMI 22 以上, 22 未満の 2 群間で, 柿帶煎液の有効性を検討したが，有意な差は認め られなかった（表 3)。しかし, 本研究ではBMI について詳細な層別化を行い検討することができ ていない. BMIについても今後症例を集積し, 詳細な検討を行う必要がある.

柿帶湯および柿帶煎液は中枢性吃逆に対する有 効性が末梢性吃逆に対する有効性よりも高いこと が報告されている. ${ }^{5,6)}$ 一方で，脳疾患関連吃逆に 対する柿帶煎液の使用は化学療法関連吃逆と比較

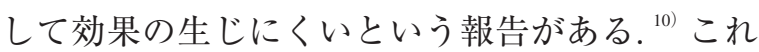
らの報告から柿帶煎液は中枢性吃逆よりも化学療 法関連吃逆により有効であることが推察された。 そこで本研究では脳転移の有無による柿帶煎液の 有効性の違いを検討したが，有意な差は認められ なかった（表 4)。これらのことから，がん化学 療法の吃逆において, 脳転移の有無によらず, 柿 楽煎液の有効性が示唆された。

化学療法による吃逆は初回化学療法施行時に $53 \%$ 発現するとの報告がある. ${ }^{25)}$ その報告では施 行回数（初回, 2 回目以降）による吃逆の発現頻

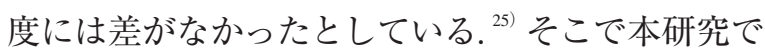
は, 施行回数（初回, 2 回目以降）について柿帶 煎液の有効性の違いを検討したが，有意な差は認 められなかった（表 5)。よって，がん化学療法の 吃逆に打いて, 化学療法の施行回数によって, 柿 帶煎液の有効性に差がないことが明らかになった。

CDDP 投与量と吃逆発現には用量依存的な関係 が報告されている. $22,27,30)$ 特に $70 \mathrm{mg} / \mathrm{m}^{2}$ 以上にお いては高頻度に吃逆が認められたとの報告もあ る. ${ }^{22)}$ 本研究では CDDP 投与量 $70 \mathrm{mg} / \mathrm{m}^{2}$ 以上, 70 $\mathrm{mg} / \mathrm{m}^{2}$ 未満の 2 群間で, 柿蔕煎液の有効性を検討
したが, 有意な差は認められなかった（表 6)。従っ て, がん化学療法の吃逆において, CDDP 投与量 によって, 柿帶煎液の有効性に差がないことが明 らかになった。

\section{4. 研究の限界}

一過性の吃逆は自然軽快することがあり, 横隔 膜の圧迫や鼻咽頭の刺激などの非薬物療法でも改 善される場合もある. 本研究では非薬物療法につ いての記載は電子カルテから 1 例もみられなかっ た. しかし, 本研究は後ろ向きの調査であるため, 自然軽快や非薬物療法の交絡を十分に調整するこ とができていない. また, 調査項目はすべてカル テの記載から判定をしているため, 想起バイアス により判定が不正確であった可能性は否定できな い.これらの点については今後適切な対照群を設 けて，ランダム化比較試験を検討していく。

\section{結＼cjkstart論}

がん化学療法における吃逆に対して柿帶煎液の 有効性が示唆された.

\section{利益相反}

開示すべき利益相反はない.

\section{引用文献}

1) Kolodzik PW, Eilers MA, Hiccups (singultus): review and approach to management, Ann Emerg Med, 1991, 20, 565-573.

2) Ripamonti C, Fusco F, Respiratory problems in advanced cancer, Support Care Cancer, 2002, 10, 204-216.

3) Minami E, Shibata H, Nunoura Y, Nomoto M, Fukuda T, Efficacy of shitei-to, a traditional Chinese medicine formulation, against convulsions in mice, Am J Chin Med, 1999, 27, 107-115.

4) Minami E, Shibata H, Nomoto M, Fukuda T, Effect of shitei-to, a traditional Chinese medicine formulation, on penthlenetetrazol-induced kingling in mice, Phytomedicine, 2000, 7, 69-72.

5）齋藤幹央, 宇野勝次, 本田吉穂, 渡辺 徹, 難治性 吃逆における柿帶湯の臨床効果, 医療薬学, 2001, 
27, 29-32.

6) Hosomi K, Kubo Y, Okuno A, Umetani Y, Hashimoto M, Araya T, Komori H, Hirai M, Matsuyama K, Clinical Efficacy of Shitei-decoction for Hiccups, Jpn J Pharm Health Care Sci, 2005, 31, 228-232.

7）角藤 裕, 清水元気, 山岡傳一郎, 吃逆に対する柿 帶湯の効果, 日本東洋医学雑誌, 2018, 69, 161-167.

8）田村博文, 柿帶湯が著効した肝細胞癌破裂後吃 逆の 1 例, 漢方の臨床, 2008, 55, 567-571.

9）山田寛幸, 武田純三, 進行胃癌および肺癌患者の 吃逆に対する柿帶湯エキスの効果, 痛みと漢方, 1997, 7, 37-39.

10）細谷龍一郎, 石坂範子, 永村陽一郎, 野澤（石井） 玲子, 網野 猛, 鎌田智幸, 日野斉一, 加賀谷肇, 植沢芳広, 吃逆に対する柿のへ夕煎の有効性, 癌 と化学療法, 2019, 46, 1165-1170.

11) Wang $T$, Wang $D$, Metoclopramide for patients with intractable hiccups: a multicenter, randomized, controlled pilot study, Intern Med J, 2014, 44, 1205-1209.

12) Porzio G, Aielli F, Verna L, Aloisi P, Galletti B, Ficorella $\mathrm{C}$, Gabapentin in the treatment of hiccups in patients with advanced cancer: a 5-year experience, Clin Neuropharmacol, 2010, 33, 179-180.

13) Friedgood CE, Ripstein $\mathrm{CB}$, Chlorpromazine (thorazine) in the treatment of intractable hiccups, JAMA, 1955, 157, 309-310.

14）納 光弘, Hiccoughの病態と薬物療法 - 自験 32 症例の分析 - , 神経内科治療, 1988, 37, 309-313.

15) Maximov G, Kamnasaran D, The adjuvant use of lansoprazole, clonazepam and dimenhydrinate for treating intractable hiccups in a patient with gastritis and reflux esophagitis complicated with myocardial infarction: a case report, BMC Res Notes, 2013, 6 , 327.

16) Ramirez FC, Graham DY, Treatment of intractable hiccup with baclofen: results of a double-blind randomized, controlled, cross-over study, Am J Gastroenterol, 1992, 87, 1789-1791.

17）原田雅史, 安藤俊平, 福島大輔, 植草啓之, 北島 悟, 野本 淳, 近藤康介, 原田直幸, 宮崎親男, 根本匡章, 周郷延雄, 脳幹梗塞に起因した難治性 吃逆に药薬甘草湯が奏功した 2 症例, 東邦医学 会雑誌, 2012, 59, 133-137.

18）榎本澄江, 寺田 哲, 木村理恵, 林 映至, 新井 丈郎, 奥田泰久, 難治性吃逆患者 8 例の治療経験, 日本ペインクリニック学会誌, 2017, 24, 35-37.

19）日本病院薬剤師会監修, “病院薬局製剂”, 第 6 版, 薬事日報社, 東京, 2008, p7.
20) Kanda $Y$, Investigation of the freely available easy-touse software "EZR" (Easy R) for medical statistics, Bone Marrow Transplant, 2013, 48, 452-458.

21) Liaw CC, Wang $\mathrm{CH}$, Chang HK, Liau CT, Yeh KY, Huang JS, Lin YC, Gender discrepancy observed between chemotherapy-induced emesis and hiccups, Support Care Cancer, 2001, 9, 435-441.

22）林 誠, 杉村勇人, 菅 幸生, 河原昌美, 相宮 光二, 宮本謙一, シスプラチン化学療法における 吃逆の危険因子に関する検討, 医療薬学, 2009, 35, 89-95.

23）浅野 肇, 渡辺瑞貴, 川口明範, 桝江正嗣, 船上 仁範, 和田哲幸, 松野純男, 山添 譲, 西田升三, 市田成志, CDDP化学療法における吃逆発現因 子の探索と制吐療法の評価ークラスター分析を 用いて - , 癌と化学療法, 2013, 40, 1031-1036.

24) Kang JH, Hui D, Kim HG, Kang MH, Lee GW, Bruera E, Corticosteroid rotation to alleviate dexamethasone-induced hiccup: a case series at a single institution, J Pain Symptom Manage, 2012, 43, 625-630.

25) Lee GW, Oh SY, Kang MH, Kang JH, Park SH, Hwang IG, Yi SY, Choi YJ, Ji JH, Lee HY, Bruera E, Treatment of Dexamethasone-Induced Hiccup in Chemotherapy Patients by Methlprednisolone Rotation, Oncologist, 2013, 18, 1229-1234.

26) Lee GW, Kim RB, Go SI, Cho HS, Lee SJ, Hui D, Bruera E, Kang JH, Gender Differences in Hiccup Patients: Analysis of Published Case Reports and Case-Control Studies, J Pain Symptom Manage, 2016, 51, 278-283.

27) Hosoya R, Tanaka I, Ishii-Nozawa R, Amino T, Kamata T, Hino S, Kagaya H, Uesawa Y, Risk Factors for Cancer Chemotherapy-induced Hiccups (CIH), Pharmacology \& Pharmacy, 2018, 9, 331-343

28) Calsina-berma A, Garcia-Gomez G, GonzalezBarboteo J, Porta-Sales J, Treatment of chronic hiccups in cancer patients: a systematic review, $J$ Palliat Med, 2012, 15, 1142-1150.

29) Steger M, Schneemann M, Fox M, Systemic review: the pathogenesis and pharmacological treatment of hiccups, Aliment Pharmacol Ther, 2015, 42, 1037 1050.

30) Liaw CC, Wang CH, Chang HK, Wang HM, Hung JS, Lin YC, Chen JS, Cisplatin-related hiccups: male predominance, induction by dexamethasone, and protection against nausea and vomiting, J Pain Symptom Manage, 2005, 30, 359-366. 